\title{
Innovation Researches of Bilingual Teaching Models in Business Communication Based on Task-driven Teaching Method
}

\author{
Fashuang HUANG $^{1, a}$, Xi YANG ${ }^{2, b}$ \\ ${ }^{1}$ Wuhan Business University, Wuhan, 430056, China \\ ${ }^{2}$ Wuhan Business Universities, Wuhan, 430056, China \\ aemail: 49241462@qq.com, bemail: 790227783@qq.com
}

\section{Keywords: Business Communication; Bilingual; Teaching Models}

\begin{abstract}
As a compulsory course of economy and management specialty, Business Communication correlates the theory with practice. It is the course teacher who considers how to put the content students have learned into practice. Task-driven teaching method, taking teaching modules and projects as the carrier and driven by specific work tasks, is the integration of theory and practice which makes students acquire new knowledge and improve skills during the process of accomplishing work tasks. The course features of Business Communication offers an opportunity to perform the task-driven method. Therefore, the author attempts to give lessons of Business Communication with the aid of task-driven teaching method and explore the feasibility and effectiveness of bilingual teaching in this paper.
\end{abstract}

\section{Introduction}

China's National Middle and Long Term Talents Development Plan Outline (2010-2020) raises that the main goal of colleges is to cultivate international talents with international vision, being familiar with international rules and capable of participating in international affairs and international competitions. Besides, international talents also should possess solid professional knowledge, strong ability of cross-cultural communication and other basic qualities which all require solid English skills. [1] As a course usually set up in the economy and management specialty, Business Communication is the first bilingual compulsory course and a practical technology course rooted in life. [2] It teaches students who may work on international trade, marketing, financial management and other international businesses in the future and is designed to help them master the basic knowledge and fundamental principles of business communication, cultivate their interpersonal skills, team communication and team work spirit, and the ability to achieve mastery through a comprehensive study and put what they learned into practice and application with its strong practicability and operability. [3] Considering the strong ability of English communication the course requires, it is usually set up in junior year when students already have a certain theoretical basis and learning experience, and will face senior internship, job hunting and other practical activities in which business communication and negotiation is necessary. [4] As a practical course, after the students understand the basic theory of business communication, it uses different teaching methods to cultivate and exercise their ability to apply business communication, such as business writing, business etiquette, business negotiation, business speech, job hunting and application and so on, training them as compound talents with good communication skills and laying a good foundation for their entry of workplace. [5] In the process of teaching, combined with domestic and foreign experience, the writer explores to find out a variety of teaching methods which are suitable for the bilingual course of business communication and negotiation to stimulate students' enthusiasm and cultivate their comprehensive abilities.

\section{Features of Business Communication}

Business Communication is a foundation course of economy and management specialty which is designed to help students master the basic knowledge and fundamental principles of business 
communication and be able to digest what they have learned in practice, especially to help students master and apply basic communication skills as an excellent communicator. It is also a major course which combines theory with practice. Therefore, the focus of the study lies in how to combine theory and practice.

In today's colleges and universities, the practical training of Business Communication are mostly case studies and discussions for the lack of direct contact with enterprises as well as teachers' mixed selection and organization of case analysis. Therefore, it is necessary to introduce the new teaching mode into the teaching classroom of business communication so as to stimulate students' enthusiasm and interests and make them acquire experience and digest knowledge to achieve a good teaching effect.

\section{Current situation and existing problems in the bilingual teaching of Business Communication}

Since the Ministry of Education put forward "using English and the other foreign languages to teach students positively" in article 8 of "Some Suggestions to Strengthen the Undergraduate Education of Higher Education Institutions to Improve Teaching Quality" and clearly pointed out: "undergraduate education should create conditions to use English in teaching the general course and specialized course", the bilingual teaching has become a hot topic of all kinds of education reforms in colleges and universities. However, the bilingual teaching reform is still very limited. , Zhang Jingying expresses that the bilingual teaching reform is not outstanding and needs further strengthening and improvement with the limitation of the policy and system, faculty, the quality of students and other restrictions in various aspects. Yin Ming points out that the teaching reform is separated from the requirements of enterprises because the bilingual teaching reform of Business Communication does not meet the needs of the market.

\section{A. Fuzzy cognition}

Some fuzzy cognition exists in teachers and students for understanding the bilingual teaching. Some teachers think that the purpose of the bilingual teaching is to improve Chinese students' English proficiency so that they could better master two languages and integrate into society more quickly to meet the demands of the society. While others think that bilingual teaching is aimed at enriching the students' professional knowledge with the help of English. Similarly, many students are not clear about bilingual teaching. For them, the bilingual teaching simply means teaching by using English and Chinese rather than a nonverbal specialized course taught by a foreign teacher. What's more, many teachers have no idea about the difference of bilingual teaching between undergraduate phrase and elementary stage let alone clearly clarify what course to be set up is suitable for bilingual teaching. As for how to organize the bilingual teaching and how to carry out specific operations, they do not know at all.

B. Lack of bilingual teachers

Bilingual teaching is not simply teaching a discipline with a foreign language but exhibiting very well the discipline knowledge with excellent language ability. To meet the needs, the best way for the teacher is to do researches and study with the target language all the year round. That is to say, the teacher has studied or worked overseas. However, most local colleges and universities are located in economically underdeveloped or remote areas. Due to the limitation of their own conditions, it is difficult for them to attract some highly-educated and high-level overseas returnees. On campus, teachers mainly voluntarily apply for setting up the bilingual course. As halfway decent bilingual teachers, it is difficult for them to do well in class for lack of systematic study of bilingual teaching theory and clear awareness of the connotation of bilingual teaching.

C. Lack of appropriate bilingual textbooks

For the selection of textbooks, most teachers choose classic textbooks of foreign universities. The high Price, rich content, long length and English writing of these books are all challenges for every student. Besides, because of different modes of thinking and culture between China and the West, the teaching material also has different focus: the compilation of foreign textbook follows the induction while that of domestic textbook adopt the deductive method. In addition, in the process of introduction, the original textbooks can also lag behind due to the copyright and other problems. 
For a lack of assessment from the authority, bilingual textbooks published or translated in China also have some problems such as nonstandard language, inadequate content and so on.

Innovations on the bilingual teaching of Business Communication have aroused high attention in teaching reforms of colleges and universities. However, the result is not satisfying because of the complexity of the course and difference of students' language level as well as uneven distribution of teachers. Therefore, the problem about how to perfect the current teaching researches systematically in many aspects of bilingual teaching mode such as the teaching system design, teaching methods, contents and teaching means must be solved.

\section{Task-driven bilingual teaching of Business Communication}

Based upon learners' previous learning experience, task-driven teaching gives full consideration to the learner's interests and needs so that they can finally use the target language; it also emphasizes the context and meaningful language contact through which it provides necessary conditions for second language learners to learn. In essence, the content-based instruction of foreign language teaching is a kind of communicative language teaching method. Essentially, it integrates the meaning construction, cognitive access, problem solving, high-level thinking and language use as well as language learning together and overcomes the separation of the language learning with content learning in traditional language teaching.

Task-driven teaching method has proved to be effective in many courses. With a clear task, students will be more active to learn and achieve much improved learning results. This teaching method advocates that effective language study is not to be taught but to experience for learning activities are as important as learning content. Therefore, the task-driven teaching method puts special emphasis on "learning by doing". By "doing things with the target language", learners can obtain abundant experience and understand the language system of the target language by themselves. More importantly, "task" provides a clear purpose for the teaching activities which highlights the significance of the meaning and effectively avoids simple emphasis of the form of language learning. What's more, due to the similarity between the "task" and the corresponding professional mission, in other words, "having a practical problem to solve", the task itself possesses many vivid characteristics required by the job and thus are more favorable to cultivate learners' professional ability and language proficiency.

Business communication is a highly practical basic subject with rich content. But for students, time is limited. The author attempts to teach students by adopting the task-driven teaching method to help them master the course in limited time. During the teaching process, the content is divided by the author into two modules: verbal communication and nonverbal communication. Each module also consists of some small modules. The verbal communication takes the speaking as the principal thing, including speech skills, listening skills, public relations etiquette and others associated with speech. While, nonverbal communication is mainly involved in writing which covers style of writing of a variety of business documents and business reports as well as matters needing attention. At the same time, in the first class, students are free association in different groups and then choose the content their team will explain later by making the draw or by free choice. Given two to three weeks for preparation; students will collect related information through searching information, brainstorming and other means. Their representative will explain the module in Chinese or simple English from the perspective of students before the teacher formally starts the lesson. In this way, having learned something about the content, students will better accept what the teacher is going to teach in English rather than giving up learning because of fear. In addition, because the class starts from students' speech, its language style is more likely to be accepted by the students and the teaching content can also be easily remembered. They can briefly introduce the content that everybody knows, shift the focus to the unclear but useful parts and add some appropriate online public classes at necessary places, acting on international conventions and relating the learning content. With appropriate details and omissions and a degree of relaxation, the method greatly improves the teaching effect instead. 


\section{Conclusion}

Task-driven teaching method makes students discuss or personally involved in the scene to complete tasks through decomposing teaching modules into teaching projects and teaching tasks, selecting or designing some real-life communication cases. These kind of teaching methods encourage students to think, analyze and solve problems independently and guide them from acquiring knowledge to improving skills which perfectly embodies "the combination of theory and practice” and completely proves “work-integrated learning” proposed by the Ministry of Education of the People's Republic of China.

\section{Acknowledgement}

In this paper, the research was sponsored by Recruitment and Employment bilingual teaching quality project.

\section{References}

[1] Breaking through the “jargon" barrier: Early 19 th century missionaries' response on communication conflicts in China[J] . Jia Si. Frontiers of History in China. 2009 (3)

[2] The nuances of being "non": Evaluating nonformal education programs and settings[J]. EmmaNorland. New Directions for Evaluation. 2006 (108)

[3] Contact Languages:Ecology and Evolution in Asia. Ansaldo Umberto. . 2009

[4] A Voyage Round the World in the Years MDCCXL,I,II,III,IV. Anson,George. . 1974

[5] EAP: issues and directions [J]. Ken Hyland,Liz Hamp-Lyons. Journal of English for Academic Purposes. 2002 (1) 